\title{
ENSURING SOCIAL SECURITY AT THE LEVEL OF LOCAL SELF-GOVERNMENT
}

Keywords: security, public safety, national security, local self-government, powers of local self-government bodies.

\begin{abstract}
The article considers public security as a component of national security. Public security is one of the priorities of state policy in the field of national security. Successful public safety is the implementation of a set of measures in the field of landscaping: installation of traffic lights in appropriate public places, construction of underpasses, construction of indoor stops for citizens waiting for the arrival of public transport, etc. A well-thought-out system of planning and construction of settlements or public places, maintaining them in good condition, which promotes work and recreation of citizens, reduces the degree of threat to public safety from the occurrence of unexpected and dangerous situations. And neglect of public amenities can lead to favorable conditions for those who commit offenses and encroach on public safety. A special place is occupied by local governments, they are the closest power to the population, have the necessary powers and resources to attract citizens to maintain public order, increase their social activity in creating decent living conditions in a given area. The state defines local self-government as an independent level of government to which the people are entitled. First of all, it presupposes the organizational separation and independence of local self-government from state power, its independence in resolving issues of local importance, but independence within its own powers, as provided by the constitution. The main powers of local governments to ensure public safety and public order include: monitoring compliance with the law in the territory; application of measures of state coercion (usually, it is a question of bringing to administrative responsibility for the offenses connected with local government); protection of public order, carried out mainly by the police; ensuring the safety of citizens. Accordingly, local governments may be endowed with additional powers in the field of public order and protection of citizens' rights. Protecting the rights of citizens is an important component of ensuring security
\end{abstract}

1 Postgraduate Student, National Academy for Public Administration under the President of Ukraine, faradzhovshamil@gmail.com. ORCID: 0000-0001-9230-3399. 
both at the individual level and at the level of the entire state. The sense of security that is transmitted inside and outside the country can be considered part of the attractiveness of the image of the country abroad.

\section{INTRODUCTION}

Ukrainian society is in the process of constantly reforming the system of public administration and various spheres of society: culture, politics, economics and social policy.

The level of public satisfaction and peace depends to a greater extent on personal and public security, which depend on the state-maintained order and security in society.

The task of ensuring the security of the individual, society and the state as a whole becomes especially relevant. At present, Ukraine is faced with the need to find and develop new ideas about the direction of further development.

The concept of national security is a state of protection of the individual, society and state from internal and external threats, which allows to ensure constitutional rights, freedoms, quality and standard of living, sovereignty, territorial integrity and sustainable development, defense and security. The set of vital interests of the individual, society, state are national interests.

The purpose of the article: to investigate and determine the degree of public safety at the local government level.

Analysis of recent research and publications. As noted by A.A. Prokhozhev, "national security is an extremely complex multilevel functional system in which the processes of interaction and confrontation of vital interests of the individual, society, and the state with threats to these interests, both internal and external, take place continuously. With such interaction and conflict of interests, other elements of the national security system, internal and external environmental factors and the activities of the governing system are constantly threatened. The purpose of this system is the degree of protection of these interests from threats" (Prokhozhev, 2005, p. 11). Thus, depending on the level (state, regional), national 
security may have its own challenges and threats, some of which may relate to one of the levels, and some may affect each of these.

National security extends to the entire territory of the country where nations and nationalities live. National security and its types can be considered as a state of vital national and state interests that arise in all spheres of society: political, economic, military, public, information, and others. In this sense, this category is similarly understood in the vast majority of countries claiming the status of world powers, including Russia, the United States, Germany, China and others. (Volkov, 2014, p. 301).

According to A.M. Voronov, "the security of the state, as well as its comprehensive support, is a complex, specific historical, socio-legal, organizational, cultural, etc. phenomenon, the study of which involves a comprehensive approach, taking into account the data of various fields of scientific knowledge.

Public security of Ukraine, in particular, is directly related to the implementation of various functions of the state: first of all, to ensure the rights, freedoms and legitimate interests of citizens; creating conditions for appropriate life and protection from internal and external threats. The implementation of the state law enforcement function involves the establishment in regulations of a set of legal means to ensure public safety in Ukraine, which must be preventive in nature and have algorithms in the event of threats that affect public safety.

Speaking of public safety, it should be noted that the sphere of public safety includes the relationship of people related to compliance with the rules of road safety, construction work in public places, fire safety, use of objects, as well as compliance with the rules of import and export of goods, cargo, vehicles and treatment of animals.

According to L.M. Rozina, public safety is a system of relations that are formed in accordance with legal norms when using objects that pose an increased danger to society, or when special conditions occur in connection with natural disasters and other emergencies (Rozin, 2009, p. 80). However, this definition does not cover all elements of social relations.

According to V.A. Osipova, the structure of social relations includes not so much social relations in various spheres of life, as social ideology and social norms of different nature (Osipov, 2008, p. 39). 
H.A. Tumanov and V.I. Frisco gives a broader definition of public safety - a set of mediated sources of increased danger, governed by legal, technical and organizational standards to prevent and eliminate threats to life, health, property and the environment (Tumanov, 1989, p. 21).

\section{THE ESSENCE OF THE CONCEPT OF PUBLIC SAFETY}

The term "public safety" is borrowed from French law in the early XIX century, when a clear line was drawn between the judicial (criminal) police and the administrative police, which was obliged to "protect public order in each area" (Kopotun, 2008, p. 26). In the Russian legal dictionary, the term "public order" was first used during the reign of Nicholas I in the Statute on the Prevention and Avoidance of Crime (1832). This term was soon found in the regulations on measures to protect public order of August 14, 1881 and in the Government Order of the Senate, signed by the King on July 12, 1889. The decree established the position of «zemstvo» head in the countryside, and its introduction was caused by "lack of strict power of strong state guardianship of the peasants".

Gradually (approximately at the turn of the $19^{\text {th }}$ and $20^{\text {th }}$ centuries) the concept of "public safety" displaces other synonymous concepts, namely:

- "devotion" - the lawful conduct of citizens in public places;

- "improvement" - rational arrangement and cleanliness of streets, squares, courtyards and entrances of houses;

- "well-being" - the normal food, medical and economic situation of the population.

In the regulations of the early Soviet state, the revolutionary order is a kind of substance of public order. The Constitution of 1936 enshrined the concepts of "public order", "public safety" and "public procurement", which emphasized their special relevance and created a basis for the application and study of laws.

The concept of "public safety" became widespread in a number of legislative acts in the 1950s and 1960s, in particular in the Decree of the Presidium of the Supreme Soviet of the USSR "On Strengthening Responsibility for Hooliganism" of July 26, 1966. This concept was formulated 
very clearly, it approved certain elements (public spaces) (Dzhuzhi, 2001, p. 368-369).

Regarding the retrospective analysis of this category, it should be noted that the concept of public order was considered in the domestic legal literature in Soviet times in two senses, which have a broad and narrow interpretation.

Public order in the broadest sense contains the whole system of social relations. from the observance and implementation of social norms, principles and ideas that work in society in all spheres of life and are socially necessary and important for this economic and political system, the behavior of citizens, government organizations and public associations (Belenkij, 1970, p. 65). In this sense, public order is the subject of protective influence of social institutions of the state.

Some authors give the following definition of public safety, public order. Public security is a state of society (system of its properties, abilities), in which due to internal social mechanisms mediated by the functioning of various state and public institutions, its stable state and development is maintained, conditions are provided for the interests of the individual, society and state and their protection (in the presence of awareness of its people) from threats arising from illegal encroachments, as well as in emergencies of social, natural and man-made nature (Pozdnyshov, 2003, p. 25).

Thus, public safety is in close relations with other types of social security - personal and state, due to the presence of a common object of protection and defense. But at the same time the specifics of public relations, which is their content, the peculiarities of legal regulation, allows to determine the scope of these phenomena, which is important for establishing the boundaries of law enforcement activities of the relevant authorities.

The challenges and threats to national security include a fairly wide range, from threats at the regional level to the threat of falsification of history and manipulation of historical memory. 


\section{ENSURING SOCIAL SECURITY AT THE LEVEL OF LOCAL SELF-GOVERNMENT}

Ensuring public safety is one of the priorities of state policy in the field of national security of Ukraine. Public security means the state of protection of man and citizen, material and spiritual values of society from criminal and other illegal encroachments, social and interethnic conflicts, as well as from emergencies of natural and man-made nature.

In ensuring public security in the long run, Ukraine proceeds from the need to constantly improve the system of public safety, as well as political, organizational, socio-economic, informational, legal and other measures:

a) to prevent, detect and stop terrorist and extremist activities, crimes related to corruption, illicit trafficking in narcotic drugs and psychotropic substances, weapons, ammunition, explosives, organization of illegal migration, trafficking in human beings, and other criminal encroachments on rights and freedoms of man and citizen, material and spiritual values of society, critical and (or) potentially dangerous objects of infrastructure of Ukraine;

b) on the prevention of social and interethnic conflicts;

c) in relation to prevention, elimination and (or) minimization of the consequences of emergencies of natural and man-made nature, including the provision of first aid to persons who are in a helpless state or in a state dangerous to their life and health;

d) to improve public administration in the field of fire, chemical, biological, nuclear, radiation, hydrometeorological, industrial and transport safety;

e) the development of international cooperation in law enforcement, as well as in the field of prevention of emergencies of natural and man-made nature and elimination of their consequences (Ivanenko, 2002).

One of the main features of public safety is that security is most effectively ensured in the presence of public order. There can be no security without order. The meaning of public order is to ensure the safety of people, their rights and interests. Strict adherence to the rules of conduct at rallies, demonstrations, sporting events that ensure public and personal safety. 
A necessary condition for the successful provision of public safety is the implementation of a set of measures in the field of landscaping: installation of traffic lights in appropriate public places, construction of underpasses, construction of indoor stops for citizens waiting for public transport, etc. A well-thought-out system of planning and construction of settlements or public places, maintaining them in good condition, which promotes work and recreation of citizens, reduces the degree of threat to public safety from the occurrence of unexpected and dangerous situations. And neglect of public amenities can lead to favorable conditions for those who commit offenses and encroach on public safety.

Here the main role in maintaining public order and protecting the population should be taken by local self-government.

In addition to assisting public authorities in addressing global security issues, local governments have their own powers in the field of public security as part of the overall security system.

At the present stage of development of Ukrainian society, the problem of democratic transformations of the state is acute. For this reason, in recent years we have been looking for the optimal model for the structure of the state mechanism, which would ensure more effective cooperation between all branches of government and optimize the activities of state bodies and local governments.

Article 7 of the Constitution of Ukraine (The Constitution of Ukraine, 1996) provides for the recognition and guarantee of local self-government in Ukraine. "Local self-government" regulates the principles of organization and functioning of local self-government and defines the main approaches to the division of responsibilities between different levels of government and local self-government.

According to opinion polls, the attitude of people to the institution of local self-government has hardly changed since the reform. The lack of a national strategy of local self-government in Ukraine has a negative impact on local self-government (Serohina, 2012, p. 19). In recent years, the state has made several attempts at the conceptual level to solve the problems of local self-government.

According to G. Ivanenko, municipal reform should ensure the active implementation of local democracy in Ukraine, strengthen relations 
between the central government and the authorities in the regions, means and methods of legal regulation of communal property to address socioeconomic problems in the region and staffing problems in the local system. self-government (Ivanenko, 2002, p. 10).

In part 2 of art. 5 of the Constitution of Ukraine (The Constitution of Ukraine, 1996) states that the people exercise power either directly or through government and local government. Thus, these are people who elect and authorize both the parliament and the President of Ukraine and local governments, namely people's deputies, elders and chairmen of village, settlement and city councils.

V. Kostytsky draws attention to the fact that the provisions of the Constitution of Ukraine indicate that the only source of power is the people, regardless of any circumstances: the people are not only the source of power but also the bearer of power (Serohina, 2012). In fact, the basic law of Ukraine introduced local self-government as an independent branch of government.

According to Article 140 of the Constitution of Ukraine (The Constitution of Ukraine, 1996) local self-government is the right of a territorial community - residents of several villages, cities and municipalities - to independently solve problems of local significance within the constitution and laws of Ukraine.

In addition, according to Article 142 of the Constitution of Ukraine, the material and financial basis of local self-government is movable and immovable property, local budget revenues, other funds, land, natural resources belonging to territorial communities of villages, settlements, cities, districts in cities, as well as objects of their common property, which are managed by district and regional councils (The Constitution of Ukraine, 1996).

In other words, the state defines local self-government as an independent level of government to which the people are entitled. First of all, it implies organizational separation and independence of local self-government from state power, its independence in resolving issues of local importance, but independence within its own powers, as provided by the constitution.

Local self-government, being the closest authority to the population, must address issues of local importance in a given area, ensure the basic 
needs of the population and therefore act in direct contact with the population. Local self-government can be considered as a relationship between local governments, between local governments and public authorities, which consists of local traditions and characteristics, the presence of democratic institutions, as well as relations in the field of ownership, independence and territorial separation.

Local self-government in the modern sense originated in the mid-19 century, and the term "local self-government" was first introduced by the German lawyer Rudolf Gneist to define the type of local self-government under which territorial communities were historically formed and had the legal right to solve local problems. At the same time, the activities of selfgoverning communities were free from the state administration and their local officials.

The main powers of local governments to ensure public safety and public order include:

1) control over the observance of the rule of law on the territory of the municipality (as a rule, it is a question of prosecutorial supervision, although other public authorities may have the appropriate control and supervision powers);

2) application of measures of state coercion (as a rule, it is a question of bringing to administrative responsibility for the offenses connected with local self-government);

3) protection of public order, which is carried out mainly by the police;

4) ensuring the safety of citizens.

Similarly, local governments may be given additional powers in the field of public order and protection of citizens' rights. Protecting the rights of citizens is an important component of ensuring security both at the individual level and at the level of the entire state. The feeling of security, which is transmitted inside and outside the state, can be considered part of the attractiveness of the image of the country abroad, thus it is a kind of "soft power" (Goloborod'ko, 2015, p. 42).

Local governments must be actively involved in addressing a significant number of issues related to public safety and law enforcement. Since part of the issues has the status of "Issues of local importance", and part - "the 
rights of local governments to address issues not related to issues of local importance."

Issues of local importance related to the sphere of public security: participation in the prevention of terrorism and extremism, as well as in minimizing and eliminating the consequences of terrorism and extremism within the municipal boundaries; participation in the prevention and elimination of the consequences of emergencies; organization of public order protection; organization and implementation of measures for civil defense, protection of the population and territory from emergencies of natural and man-made nature, including support in a state of constant readiness to use public warning systems, objects of civil defense, creation and maintenance of civil defense stocks technical, food, medical and other means.

Within the limits of their powers, local self-government bodies assist judicial bodies and the prosecutor's office in their work to ensure the rule of law on their territory. Local governments can involve citizens in the protection of public order, public organizations, enterprises, using various legal forms. For example, there may be people's wives.

Local self-government has the necessary resources and mechanisms to initiate the conscious participation of citizens, increase their social activity in creating decent living conditions in a given area, forming their responsibility for solving local problems in the context of regional and national, thereby increasing their overall social and civic activity forming a new personality.

\section{CONCLUSIONS}

Public safety is regulated by law and protected by the law on criminal liability a number of social relations in the field of ensuring normal working conditions, peace, life and tranquility of people. In our opinion, such an understanding of public safety is of great practical importance.

Promotion of further improvement of legal regulation of public safety, improvement of activity of state institutions and public organizations. This definition has certain theoretical advantages, as it allows to identify individual elements, aspects of public policy, which together allows to deter- 
mine the range of components of social relations that represent prospects for further research.

Public safety and protection of public order apply to all citizens without exception, regardless of ethnicity or race, such principles exist in all economically developed countries with a complex ethno-social structure that exists in the state. Everyone wants to live where there is no threat to the safety of life. Protection of public order is one of the most important issues of local importance. Carrying out preventive measures will ensure the formation of mutual understanding and mutual respect in citizens on issues of interethnic and intercultural cooperation in society and increase the level of ethnocultural competence both among young people and among the adult population. Local governments can most fully express and protect the interests of citizens living in the area.

\section{BIBLIOGRAPHY:}

Belenkij, V.A. (1970). O sushhnosti narushenij obshhestvennogo porjadka [On the essence of violations of public order]. Moscow: Vestnik MGU.

Dzhuzhi, O.M. (2001). Kurs kryminolohii: Osoblyva chastyna: Pidruchnyk [Crime course: Special chastina: Textbook]. Kyiv: YurInkom Inter.

Goloborod'ko, A.Yu., Serikov A.V. (2015). Diskurs «myagkoy sily» v kontekste konstruirovaniya imidzha sovremennoy Rossii: faktory i tekhnologii formirovaniya konkurentnoy identichnosti [The discourse of "soft power" in the context of constructing the image of modern Russia: factors and technologies for the formation of competitive identity]. Rostov: Omega - Press.

Ivanenko, H. (2002). Konstytutsijna model' pravovoi derzhavy: shliakhy ii udoskonalennia ta realizatsii [Constitutional model of a legal state: ways of its improvement and implementation]. (PhD Thesis), Odesa: Natsional'nyj universytet “Odes'ka iurydychna akademiya.

Kopotun, I.M. (2008). Hromads'kyj poriadok iak ob'iekt kryminal'no-pravovoi okhorony [Public order as an object of criminal law protection]. (PhD Thesis), Kyiv: Kyjvs'kyj natsional'nyj universytet vnutrishnih sprav.

Osipov, V.A. (2008). Pravovaya bezopasnost' v sisteme natsional'noy bezopasnosti [Legal security in the system of national]. Moscow: Jurist.

Pozdnyshov, A.N. (2003). Institut gosudarstvennoy sluzhby v sfere obespecheniya obshchestvennoi bezopasnosti: teoretikometodologicheskie problem [Institute of public 
service in the field of public safety: theoretical and methodological problems]. Moscow: Akademiya upravleniya MVD Rossii.

Prokhozhev, A.A. (2005). Obshchaya teoriya natsional'noy bezopasnosti [General theory of national security]. Moscow: RAGS.

Rozin, L.M. (2009). Voprosy yurisdiktsionnoy deyatel'nosti organov vnutrennikh del. Administrativnoe pravo [Issues of jurisdictional activity of internal affairs bodies. Administrative law]. Moscow: Norma.

Serohina, S. (2012). Napriamy vdoskonalennia konstytutsijnoho rehuliuvannia systemnostrukturnoi orhanizatsii mistsevoho samovriaduvannia v Ukraini [Directions for improving the constitutional regulation of the system-structural organization of local self-government in Ukraine]. Konstytutsijna Asambleia: polityko-pravovi aspekty diial'nosti: biuleten' informatsijno-analitychnykh materialiv. Kyiv: Vernadskuy NLU. Tumanov, G.A., Frizko, V.I. (1989.) Obschestvennaya bezopasnost' i ee obespechenie v ekstremal'nykh usloviyakh [Public safety and its provision in extreme conditions]. Moscow: Nauka

Verkhovna Rada of Ukraine (1996)/ Konstytutsiia Ukrainy [Constitution of Ukraine]. Downloaded from: https://zakon.rada.gov.ua/laws/show/254\%D0\%BA/96$\% \mathrm{D} 0 \% \mathrm{~B} 2 \% \mathrm{D} 1 \% 80$

Volkov, Yu.G., Vyalykh, N.A., Degtyarev, A.K., Lubskiy, A.V., Posukhova, O.Yu., Serikov, A.V., Chernobrovkin, I.P. (2015). Tsennostnaya politika i institutsional'nye praktiki v sfere mezhetnicheskikh otnosheniy v ekonomicheski razvitykh stranakh so slozhnoy etnokul'turnoy strukturoy [Value policy and institutional practices in the field of interethnic relations in economically developed countries with a complex ethnocultural structure]. Rostov: Fond nauki i obrazovaniya. 